\title{
A recombinant DNA-satellite associated with Pepper yellow leaf curl Indonesia virus in highland area
}

\author{
Argawi Kandito, Sedyo Hartono*, Sri Sulandari, Susamto Somowiyarjo \\ Department of Plant Protection, Faculty of Agriculture, Gadjah Mada University, Jln. Flora 1, Bulaksumur, Sleman, Yogyakarta 55281, \\ Indonesia \\ *Corresponding author: sedyohartono@ugm.ac.id
}

SUBMITTED 19 March 2021 REVISED 22 April 2021 ACCEPTED 27 April 2021

\begin{abstract}
Yellow curl disease caused by Begomovirus is a major threat for horticulture in Indonesia. Control measures for the disease face several constraints, one of which is the association between begomovirus and DNA satellites which can affect the severity of symptoms. In this study, we detected the presence of a DNA satellite associated with begomovirus in a highland area. The sample was obtained from Ketep, Magelang, located approximately 1400 meters above sea level. Begomovirus was detected using primers PAL1V1978/PAR1C715 that resulted in an amplicon of approximately $1600 \mathrm{bp}$. The presence of this satellite was detected using primers CLB36F/CLB37R, resulting in full-length satellite genome of approximately $1300 \mathrm{bp}$. Sequence analysis showed the sample was infected by Pepper yellow leaf curl Indonesia virus (PepYLCIV) and a non-coding satellite which resembled some characteristics of common betasatellites with imperfect putative ORF $\beta C 1$. SimPlot analysis revealed the recombination event between betasatellites and DNA-B of PepYLCIV. The satellite found in this study is thought to be the result of recombination due to multiple infections in plants.
\end{abstract}

KEYWORDS Begomovirus; DNA satellite; non-coding satellite; PepYLCIV; recombination

\section{Introduction}

Since 1999, the incidence of yellow curl disease has been a major threat for the chili cultivation and other Solanaceae in Indonesia (Hidayat et al. 1999; Sulandari et al. 2001). Yellow curly disease on chili in Indonesia is mainly caused by Begomovirus infection. There are several species of Begomovirus that cause chili yellow curl diseases i.e., Pepper yellow leaf curl Indonesia virus (PepYLCIV), Tomato leaf curl Kanchanaburi virus (TYL$\mathrm{CKaV}$ ), Tomato leaf curl Java virus (ToLCJaV), Ageratum yellow vein virus (AYVV) (Kenyon et al. 2014; Wilisiani et al. 2014). Diseases caused by begomovirus infection initially only occurred in the lowlands. But in recent years, the disease is also found in the highlands area (Kusumaningrum et al. 2017). Besides, diseases caused by begomovirus have also been reported affecting new hosts, including eggplant and luffa (Kintasari et al.; Giovanni et al. 2020). Until now, controlling measures for yellow curl diseases are still difficult because of several factors, including a broad range of hosts, high genetic diversity, the polyphagous insect vector Bemisia tabaci, multiple infections by several species, recombination among species, and the presence of satellite DNA which potentially affect the symptoms.

Begomovirus is a circular single-stranded DNA virus that belongs to the family Geminiviridae. It may possess single genome (monopartite) which only DNA-A present in a single virion, but also two genomes (bipartite) which consist of DNA-A and DNA-B in a single virion. The Begomovirus genome sized approximately 2.7-2.8kbp. The monopartite begomoviruses found in Indonesia are AYVV, ToLCV, and ToLCJaV. The bipartite begomoviruses are TYLCKaV, Tomato yellow leaf curl New Delhi virus (ToLCNDV), and PepYLCIV (Kenyon et al. 2014; Tsai et al. 2006). In addition to the two genomes, begomovirus could also be associated with DNA satellites. Several monopartite Begomovirus i.e., AYVV, ToLCJaV, and Cotton leaf curl virus (CuLCV), and the bipartite ToLCNDV and TYLCKaV were associated with DNA satellites (Kon et al. 2006; Saunders et al. 2004; Nawaz-ul Rehman et al. 2009; Agnihotri et al. 2018; Kandito et al. 2020).

There are three types of satellites being reported to be associated with Begomovirus, alphasatellite, betasatellite, and deltasatellite. Recently, these satellites are grouped into two families Tolecusatellitidae and Deltasatellitidae (Zhou 2013; Lozano et al. 2016; Fiallo-Olivé and NavasCastillo 2020).

The presence of satellites could affect symptom severity. In example, betasatellites were reported to exacerbate 
the symptom, while alphasatellites were vice versa (Dry et al. 1997; Briddon et al. 2001; Zhang et al. 2012; Zhou 2013; Idris et al. 2011). Meanwhile, deltasatellites which sized approximately only half of their counterparts, consisted of non-coding region and were also reported to reduce symptom severity (Zhou 2013). In this study, we aimed to detect the presence of satellite associated with severe symptoms of the yellow disease on chili in the highland area and analyze the molecular characteristic of the satellite.

\section{Materials and Methods}

\subsection{Sampling location}

Leaf sample was collected from chili plantation in Ketep, Magelang, Central Java, located approximately 1400 masl. Sampling was conducted in 2018. Ketep was chosen as a sampling site because it is one of the horticulture production areas in Central Java and reported as endemic area of begomovirus infections, as reported by Kusumaningrum et al. (2017). Symptom appearance of the sample was mosaic, leaf yellowing, stunting, which are common symptoms of begomovirus infection (Figure 1).

\subsection{DNA Extraction}

A hundred milligrams of fresh sample was used for total DNA extraction. The sample was ground using porcelain mortar and pestle without liquid nitrogen. The DNA extraction protocol was carried out using a total DNA extraction kit for plants (Geneaid, Germany). Extraction steps were done following manufacturer instructions. Total genomic DNA was subsequently used as a template for amplification.

\subsection{Detection and amplification using $P C R$}

Polymerase Chain Reaction (PCR) was carried out using MyTaq Redmix Polymerase (Bioline), $\mathrm{ddH}_{2} \mathrm{O}$, forward primer, reverse primer, and DNA templates. The reaction was carried out in a volume of $50 \mu \mathrm{L}$. The primer sequences used in this study were in Table I. The PCR program for the primary pair PALIV1978/ PAR1C715 which amplified the Begomovirus partial DNA-A region, i.e., pre-denaturation at $95{ }^{\circ} \mathrm{C}$ for $3 \mathrm{~min}$, followed 40 cycles of denaturation at $95^{\circ} \mathrm{C}$ for $1 \mathrm{~min}$, attaching (annealing) at $55^{\circ} \mathrm{C}$ for $30 \mathrm{~s}$, extension for $1 \mathrm{~min} 30 \mathrm{~s}$. The final extension was at $72^{\circ} \mathrm{C}$ for $10 \mathrm{~min}$. The PCR program for the CLB36F/CLB36R primer amplified the full length of betasatellite consists of pre-denaturation at $95^{\circ} \mathrm{C}$ for $3 \mathrm{~min}$, followed 40 cycles of denaturation at $95^{\circ} \mathrm{C}$ for $1 \mathrm{~min}$, annealing at $58{ }^{\circ} \mathrm{C}$ for $30 \mathrm{~s}$, extension for $1.5 \mathrm{~min}$. The final extension was at $72{ }^{\circ} \mathrm{C}$ for $10 \mathrm{~min}$. Visualization of PCR products was carried out by agarose gel electrophoresis $1 \%$ ( w / v) using $50 \mathrm{~V}$ power for $50 \mathrm{~min}$.

\subsection{Sequencing and sequence analysis}

Sequence analysis of begomovirus was conducted using the direct Sanger sequencing method of PCR products.

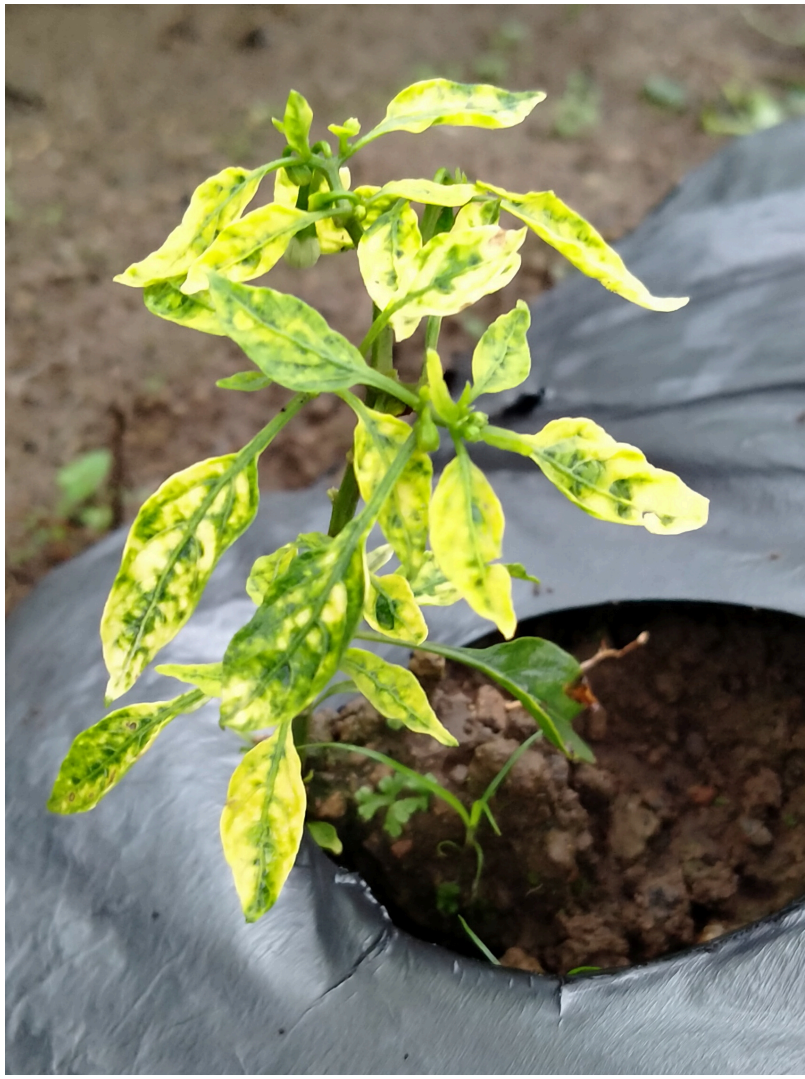

FIGURE 1 Chili (Capsicum annuum) planted in Ketep, Magelang (1400 masl) showed mosaic and yellowing symptoms.

The sequence of the betasatellite was performed by the cloning method using the T7 plasmid. Analysis of sequence results was carried out with the MEGA v.7 program (Kumar et al. 2016), BLAST (http://blast.ncbi.nlm .nih.gov/Blast_cgi), Clustal Omega (http://ebi.ac.uk/Tool s/msa/clustalo/), and ORFFinder (https://www.ncbi.nlm .nih.gov/orffinder/). The phylogenetic analysis uses the Neighbor-Joining method with 1000 bootstraps (Efron et al. 1996). The recombinant analysis was performed using Simplot v3.5.1. (Lole et al. 1999). Analysis of unique structures was performed using alignment analysis. Subsequently, the satellite sequence was submitted to Genbank with accession number MN905560. Satellites genome diagrams were created using BioRender (http: //biorender.com).

\section{Results and Discussion}

\subsection{Result}

Chili sample found in the Ketep area, Magelang showing several symptoms including mosaic, dwarfism, vein enation, and curling which are typical symptoms of Begomovirus infection in chilies. Begomovirus detection was carried out by PCR method using primer pair PALIV1978 / PARIC715 which amplifies partial DNA-A. PCR results showed positive results for DNA bands measuring 1600bp (Figure 2a,). The detection of betasatellites was 

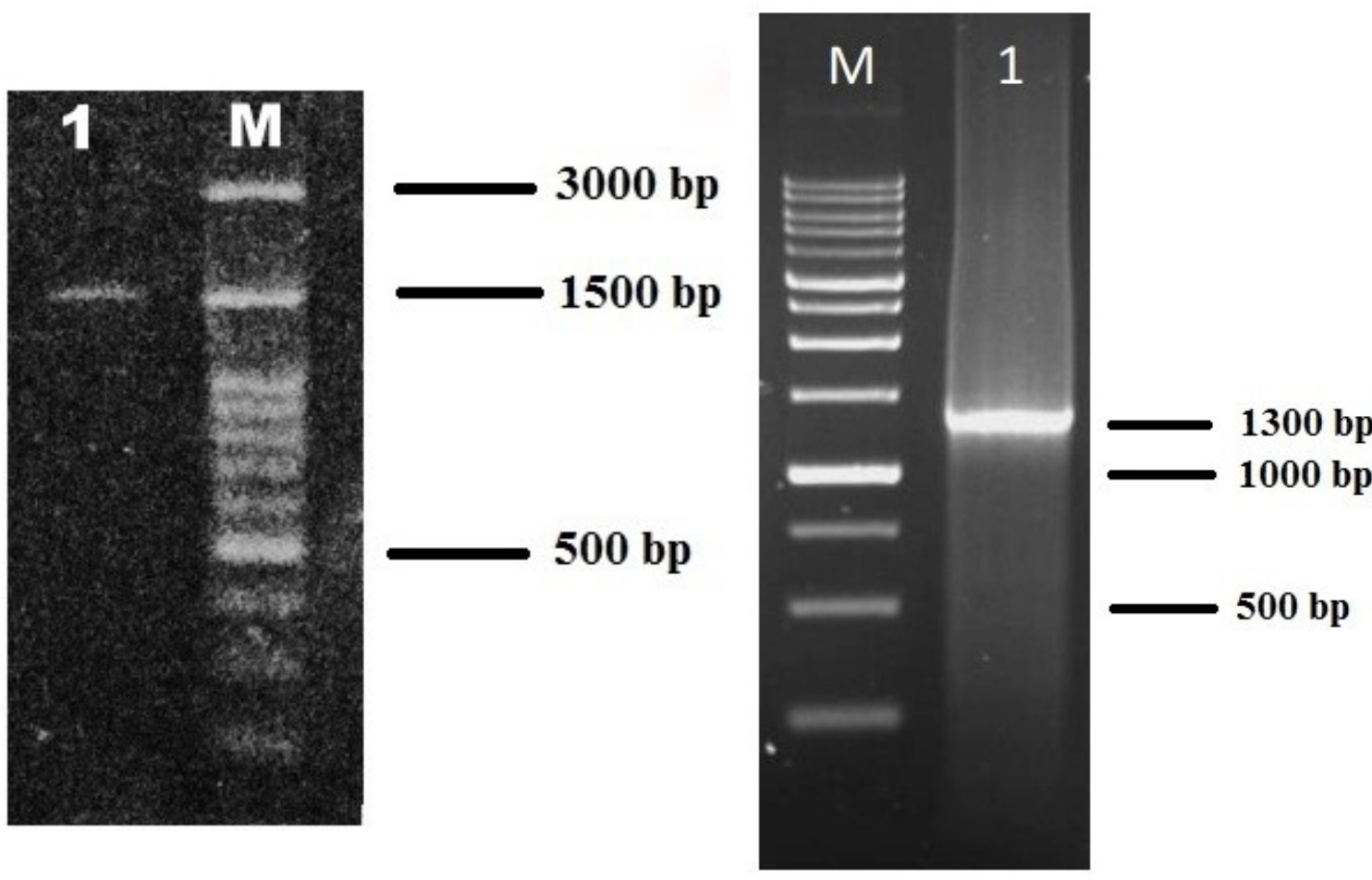

(a)

(b)

FIGURE 2 Visualization on agarose of PCR amplified sample using PAL1V1978/PAR1C715 (a) and CLB36F/CBL37R (a). M is 1kb DNA Ladder

carried out using the CLB36F / CLB37R primers pair which amplified the intact beta genome of the satellite. PCR results showed a positive result in the form of a DNA band with a size of $1300 \mathrm{bp}$ (Figure 2b). This suggests that the presence of betasatellite accompanies PepYLCIV infection in this samples.

The results of the begomovirus PCR sequence showed that the sample was infected with PepYLCIV with a homology percentage up to $100 \%$ compared to the PepYLCIV sequences obtained from Genbank. Phylogenetic analysis using Neighbor-Joining with 1000 boorstraps shows the sample is in the Indonesian PepYLCIV cluster (Figure 3). PepYLCIV is a species of begomovirus commonly found in Indonesia and has been reported to be a major problem in Solanaceae cropping since 1999. It was also reported that PepYLCIV is a begomovirus which is endemic in Indonesia. The incidence of yellow leaf curl caused by PepYLCIV in various Solanaceae can reach $100 \%$, with the value of losses varying depending on the time of infection.

The nucleotide sequence of betasatellite shows that the satellite accompanies the infection resembling betasatellites which associated with ToLCV and AYVV, and has similarities to the non-coding region part of DNA-B on PepYLCIV. Phylogenetic analysis using the Neighborjoining method shows that this satellite is located in a cluster with satellites associated with ToLCV and AYVV, and has proximity to the non-coding satellite previously re-

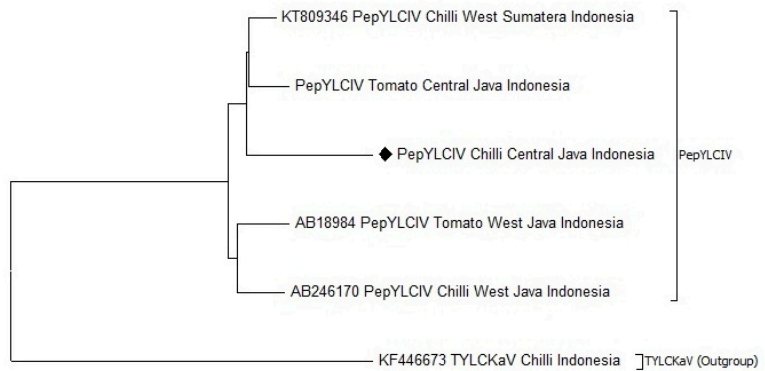

$\stackrel{0.05}{2}$

FIGURE 3 Phylogenetic diagram of PepYLCIV constructed using Neighbor-Joining method with 1000 bootstraps. Sequence of this research marked by black diamond. TYLCKaV is an outgroup.

ported to be associated with TYLCKaV (Kandito et al. 2020) (Figure 4). The sequencing and characterization results of the satellite showed a non-coding satellite that was thought to be a recombination of betasatellite with PepYLCIV DNA-B. This satellite has an SCR resembling ToLCB, an imperfect ORF $\beta C 1$, and a similarity to PepYLCIV DNA-B intergenic region spanning between ORF BV1 and BC1 .

Further analysis of satellite sequences was carried out by looking at the sequence profile on 3 main parts of the satellite, namely the satellite conserved region (SCR) which contains the stem-loop structure TAATAT- 


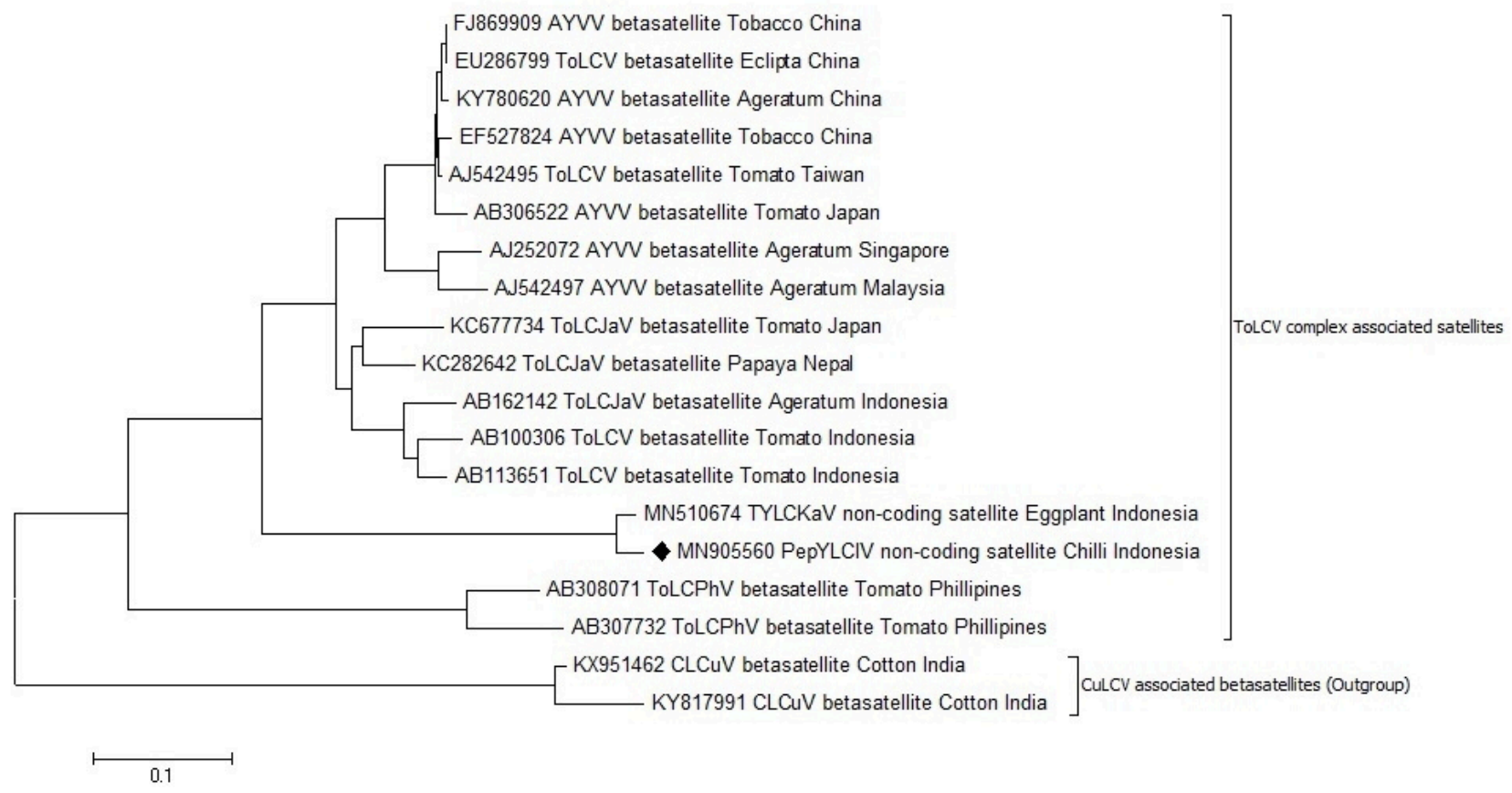

FIGURE 4 Phylogenetic diagram of betasatellites obtained from Genbank constructed using Neighbor-Joining method with 1000 bootstraps. Sequence of this research (MN805560) marked with black diamond.

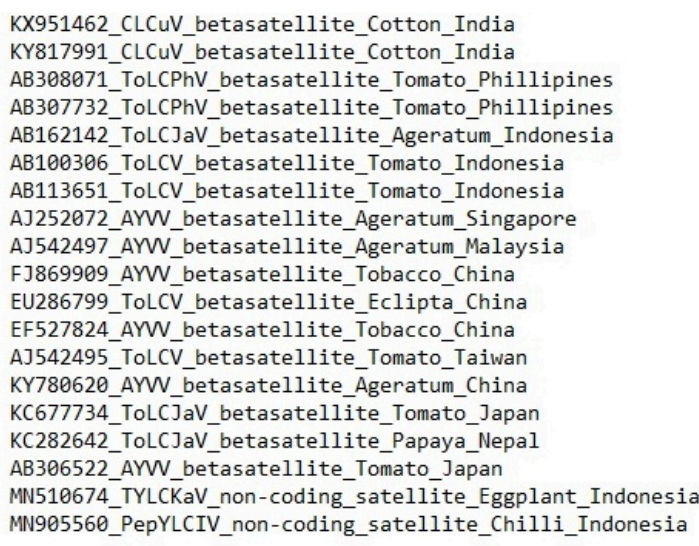

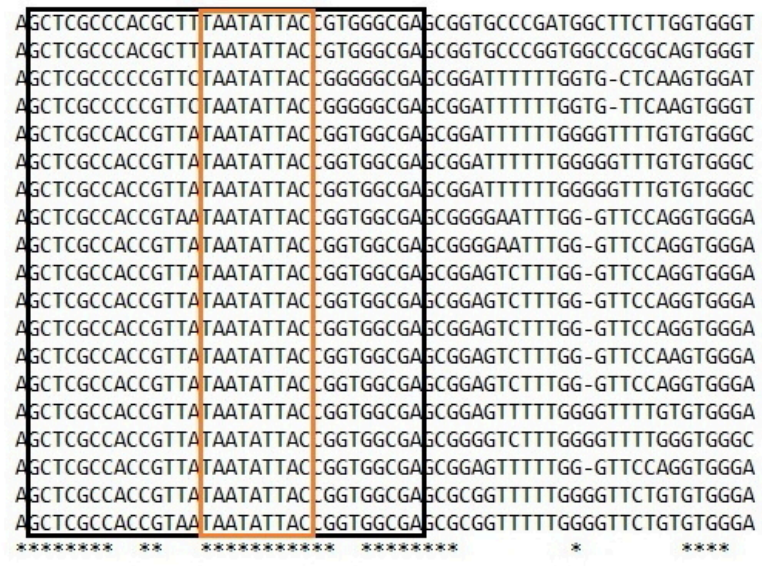

FIGURE 5 Stem-loop region (black box) and conserved nonanucleotide TAATATTAC region (orange box) of DNA satellites.

TAC, ORF $\beta C 1$, and adenine rich region. The alignment in the SCR and stem-loop regions has significant similarities to the sequences obtained from Genbank (Figure 5). The similarities in the SCR area indicated that the satel-

TABLE 1 Oligonucleotide primers used in this study.

\begin{tabular}{lll}
\hline Primers & $5^{\prime}-3^{\prime}$ & References \\
\hline PAR IC 715 & GATTTCTGCAGTTDATRT- & \\
& TYTCRTCCATCCA & (Rojas 1993) \\
PAL IV 1978 & $\begin{array}{l}\text { GCATCTGCAGGCCCA- } \\
\text { CATYGTCTTYCCNGT }\end{array}$ & \\
CLB36F & CCTTAGCTACGCCGGAGCT & (Kumar et al. 2018) \\
CLB37R & AAGGCTGCTGCGTAGCGTAG & \\
\hline
\end{tabular}

lites are shared common features. Thus they might resemble each other. Alignment in the putative ORF $\beta \mathrm{C} 1$ region showed the presence of insertion of 42 nucleotides (14 amino acids, no 56-70, Figure 5) and the presence of several stop codons located in that region. This resulted in an imperfect ORF of $\beta C 1$ in the sample and it was a non-coding region (Figure 6). Schematic diagram of the non-coding satellite compared with common betasatellite shown in Figure 7.

The percentage of adenine in the Adenin-rich region reaches $66.67 \%$. This section presents a secondary stemloop structure along 24 nucleotides TCGATTAACATACACGTTAATCGA which can also be found in the non DNA-B coding PepYLCIV in Java (AB213599). Similar parts between the satellite and its helper virus indicate the 
KX951452_CLCLN_betasatellite_Cotton_India KY817991 CLCUN betasatellite cotton Indis AB 398971_ToLCPhV betasatellite_Tomato Phillipines AB 397732 ToLCPhy betasatellite_Tonato_phillipines

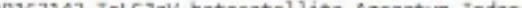
AB162142_ToLe Jav_betasatellite_Ageratun_Indonc: AB10eja6_ToLCV_betasatellite_Tomato_Indonesis AB113651_ioLCV_betasatcllite_fonato_Indonesia A 252872 _ArW_Ectasatellite_Ageratun_Singapor A 542497 _AYW_betasatellite_Ageratun_Malaysis F J869909_AYW_ betasatellite_Tobacco_Chino EU286799_ToLCV__betassatellité_Eclipta_China EF527824_AYV _betasstellite_Tobacco_China AJ542495 ToLCV betasatellite_Tomato_Taiwan KY78E62B_AYW betasatellite_Ageratum_China KC677734 ToLCJaV betasatellite Tomato Japan KC282642 ToLCJaV betasatellite Papaya Nepal AB396522 AYW betas atollite. Tom to Japan

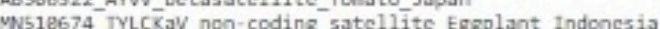
weass6e_PepYLCIV_non-coding_satellite_Chilli_Indonesis

KX951452_CLCuN_betasatellite_Cotton_India krs17991_CLCuN_betasatellite_Cotton_Indis AB398971_ToLCPhW_betasatellite_Tomato_Phillipines AB 397732 ToLCPhV betasatellite_Tomato_Phillipines AB16.2142 ToLCJaV betasatellite Ageratur Indones is AB10e3e6_ToLCV_betasatellite_Tonato_Indonesis AB113651 ToLCV betasatellite Tonato Indonesia A.J252072 AYV betasatellite_Ageratun Singapore AJ542497-AYW betasatcllite-Ageratur Malaysis FJ869909-AYW betasatellite_Tobacco China EU286799 TolcV betasatellite Eelipta China EF527824 AYW betasatellite Tobacco_China A]542495_ToLCV_betasatellite__omato_Taiwan KY788628_AYW_betasatellite_Ageratun_China KC6777 34_ToLCJav_betasatellite_Tomató_Japan KC28264Z_ToLCJaV_betasatellite_Papaya_Nepal AB396522_AYW_betasatellite_Tómato_Japan MN518674 TYLCKaV non-coding_satellite_Eggplant Indones ia Mvees56e_PepYLCIV__non-coding_sstellite_chilli_Indonesis

KX951462 CLCUN betasatellite cotton Indis Krg17091 CLCuN betaratellite Cotton India AB398971_ToLCPhiV_betasatellite_tomato_Phillipines AB397732_ToLCPhi_betasatellite_Tomato_Phillipines AB162142_ToLCJaV_betasatellite_Ageratur_Indoncsi AB10e3e6_ToLCV_betasatellite_Tomato_Indonesis AB113651_ToLCV_betasatellite_Tomato_Indonesia A. 252072 AYW betasatellite_Ageratum_Singapore A. 542497 AYW betasatellite Aperatum Malsysis FJ8699e9 AYV betasstellite Tobacco Chins EU1286799 ToLCV betaratellité Eclipta Chin

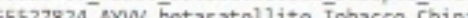

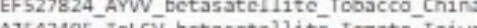
protes KCr7se628KC677734_ToLCJaV_betasatellite_Tomato_Japan KC282642_ToLCJaV_betasatellite_Papaya_Ncpal AB396522_AYV__betasatellite_Tónato_Japan

WN518674_TYLCKaV_non-coding_satellite_Eggplant_Indonesia Mw9as56e_PepYLCIV_non-coding_satellite_Chilli_Indonesia

MITSGINKKGVRF IVDNRIMENMKIFIHYRILSTKSPSLIKYEGIIOYRYEDIHAPFDMITSGINKKGVRF-IVDVRIMENYKIFIHNRILSTKSPSLIKYEGIIOYRYEDIHYPFD - MII TYKNTKGNSFVINRLRRENSISVEIDLFLTKKPFLLFKECFIIPYGFOGIIAPFG MTI TYKNTKGMIFVINWRL IRKENSISVEIDLFL TKKPFLLHKECFIIPYGHOGIIIPFD-

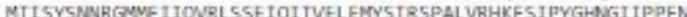

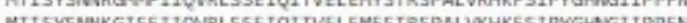

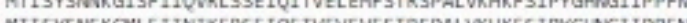

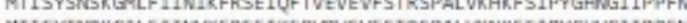

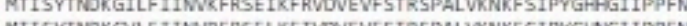

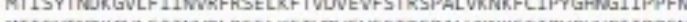
MIISYTNDKGVLFIIMVRLRSELKFTVDVEVFSTRSPALVKNKFSIPYGHHGIIPPFN MIISYTNOKGVLFIINWRLRSELKF TVDVEVFSTRSPALVVNKFSIPYGHAGIIPPFN MIISHINDKGVLFIINWRLRSELKF TVDVEVFSIRSPALVKNKFSIPYGHHGIIPPFN MTISYTNDKGVLFIINWRLRSELKFTVDVEVFSTRSPALVKNKFSIPYGHAGIIPPFN MIISYTNOKGVLFIINRLLSELKFTVWVEVSTRSPALVKNKFSIPYGFHGIIPPFN MTISYFNWOGWVF IINWRIKSEMOLADEVEMLSTRSPAVWKHKFSIPYGHAGINPPFN MTISYSNSKGNIFIINIKFRSEIOFTVEVEVFSTKSPALVKHKFSIPYGHNGIIPPFN

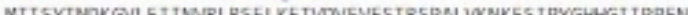
MTSFLEKG

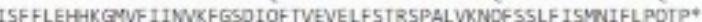

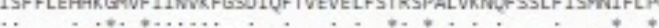

C........FNGFEGSIIANFLFAYNEAKIEEFEIEDIVHRLOILVLENPELLGINN FNGF EGSIIANF LFAYNEANIEEFEIEDIVHRLOILVLENPEILGIN FNDLEEGLKGL INIMYADSPAEEFRHEDNWESIDILMVNEAPWVDNI FNDIEEGIKGIINIYYADSSPAEEFRHEDMNEAIOILNWNEAPVEINI

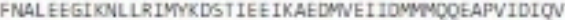
FNAL EEGIKONL L RIMTYKDSSIEE I KAEDMNEIMOMMNOOEAPVIDIOV FNAL EEGIKNLLLRIMYKDSSIEEIKAEDMNEI TDMMYOOEAPVIDICN

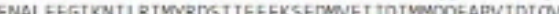

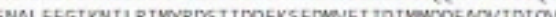

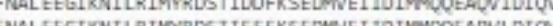
- FRL LEG Fule

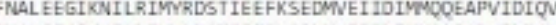
FNALEEGIKNILRIMYRDSTIIEEFKSEDMNEI IDIMMQQEAPVIDIQQN FNAL EEGIKNTLRIMYRDSTIIEEFKSEDMNEI IDIMMCOEAPVLDION FNAL EEGIKNNXLRIRYRDSTIIEEFKSEGRVEI IOMWMCOEAPVIDION FNALEEGIKNLLLRIMYRDSTIIEEFKSEDNNEI IOMMIOOEAPVIDION ENAL EEGIKNILRIMYRDST IEEFKSEDNVEI IOIMVHOEAPVIDIQV

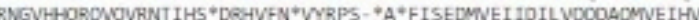

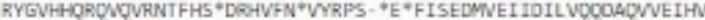

$$
\text { ( }
$$

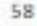

58

58

58

FIGURE 6 Alignment of putative ORF $\beta C 1$ of sample (MN905560) compared with sequences obtained from Genbank performed using ClustalOmega. There are 14 amino acid insertions and several stop codons of the sample sequence, (amino acid no 56-70), resemble a non-coding region.

possibility of recombination and transreplication between satellites and their helper viruses.

Recombination event was determined using SimPlot program v3.5.1 with a comparison between betasatellites, PepYLCIV-non coding satellite, and PepYLCIV DNA-B (Figure 8). The result showed that the PepYLCIV-non coding satellite was a possible recombinant between betasatellites and PepYLCIV DNA-B. This leads to a presupposition that mixed infection between begomoviruses and satellites may occur in the field, as the whitefly, the specific vector of begomovirus could contain more than one species of begomovirus (Sidik et al.; Purwoko et al. 2015). The recombination phenomenon between begomoviruses and their satellites was reported by Huang et al. (2013).

\subsection{Discussion}

The virus-satellite complex that infects a plant can result in recombination between viruses and satellites, satellites, and other satellites, giving rise to defective DNA (dfDNA / diDNA), or transreplication. Transreplication is a virus that can acquire and reproduce satellites from other viruses (Zhou 2013; Nawaz-ul Rehman et al. 2009). In this study, the secondary stem-loop structure that was found in the non-coding satellite was also found on satellites associated with the group Sweepovirus and recombinant satellites (Huang et al. 2013; Lozano et al. 2016). The incident so far could have several consequences namely exacerbating symptoms, relieving symptoms, not affecting symptoms at al. or generating new satellites. (Huang 


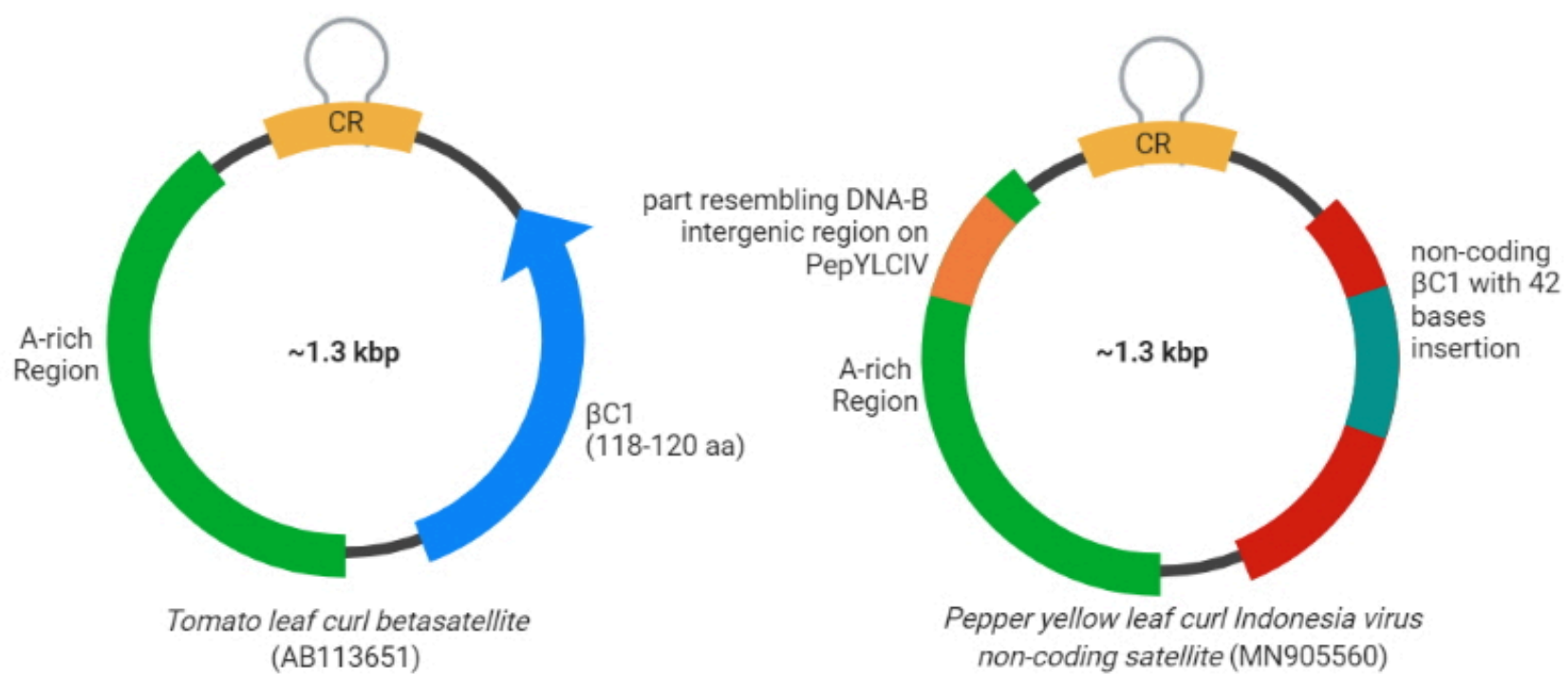

FIGURE 7 Schematic diagram of the non-coding satellite genome associated with PepYLCIV compared with common betasatellite genome. The figure was created with BioRender (http://biorender.com).

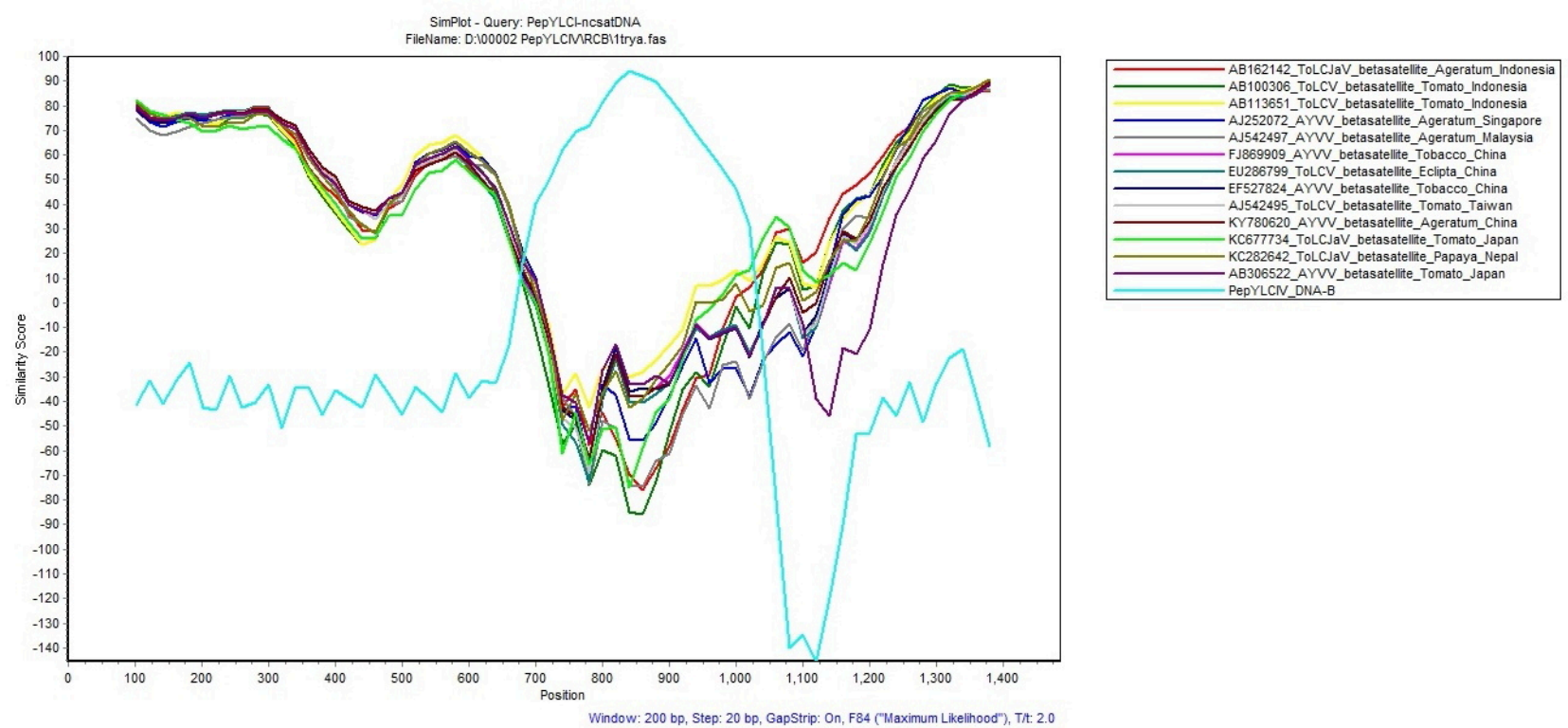

FIGURE 8 Recombinant analysis using SimPlot showing possibility of PepYLCIV-non coding satellite (MN905560) as a result of recombination event between betatellites and a part of PepYLCIV DNA-B. Recombination event was detected between common betasatellites and DNA-B of PepYLCIV (base no. 700-1000).

et al. 2013) reported a non-coding recombinant satellite which is the result of natural recombination between betasatelite associated with Tomato yellow leaf curl China virus (TYLCCNB), betasatellite associated with Ageratum yellow vein China virus (AYVCNB) and Tobacco curly shoot alphasatellite TbCSA) can be transreplicated and maintained by the Tobacco leaf curl Yunnan virus (TbLCYNV). Nawaz-ul Rehman et al. (2009) reported the incidence of transreplication between betasatellite associ- ated with Cotton leaf curl Multan virus (CLCuMuB) and Cabbage leaf curl virus (CbLCuV), resulting in a betasatellite progeny that could be transreplicated with other begomoviruses from the New World group. Incidence of natural recombination between ToLJaV, AYVV, and betasatellites into new satellites suspected to be due to mixed infection of several viruses in a plant (Kon et al. 2006; Nawaz-ul Rehman et al. 2009; Huang et al. 2013). These phenomena were apparently the result of complex, multiple infections 
of viruses on a single host. Several reports indicated that begomovirus, betasatellite, and alphasatellite could have coexistence due to shared genome similarity (Huang et al. 2013; Emmanuel et al. 2020). Thus, each component has a similar probability to resulted in recombination or a defective genome.

Meanwhile, the conserved region of the begomoviruses and their satellites, which contain TAATATTAC motifs, indicated similarities between the virus and the satellite. The TAATATTAC also served as the origin of replication for both virus and satellites (Yang and Zhou 2017). On the virus side, the origin of replication belongs to both DNA-A and DNA-B, especially served for maintaining DNA-B, since DNA-B has no Rep gene and it could not replicate autonomously. The DNA-B replication depending on the Rep gene activity on the DNA-A. This has also happened with the replication of betasatellites (Yang and Zhou 2017). Briddon et al. (2010) hypothesized that the DNA-B might result from wild satellites, which apparently integrated as the second genome of begomovirus. On the other hand, betasatellite could replace the DNA-B component by facilitating systemic infection and cellular movement through the $\beta \mathrm{C} 1$ gene expression. Thus it can be one of the pathogenicity determinants for the virus infection (Saeed et al. 2007; Saunders et al. 2004; Briddon and Stanley 2006).

In this study, the non-coding satellite is presumed to be the result of coinfection between PepYLCIV, a bipartite begomovirus, with another begomovirus with satellite. The BLASTn result indicated that the satellite is apparently a recombinant satellite. Phylogenetic results of betasatellites showed the satellite in this study grouped with ToLCV-associated betasatellites, including non-coding satellite associated with TYLCKaV (MN510674), and ToLCPhV-associated betasatellites.

Further analysis using SimPlot v3.5.1. based on nucleotide alignment indicated the recombination occurred between a betasatellite with the DNA-B component of PepYLCIV. The recombination itself is common among begomoviruses or begomovirus-satellites, since each genome shared a similar origin of replication, and both DNA-B and betasatellites are dependent on DNA-A for their maintenance (Huang et al. 2013). However, the occurrence of begomovirus-betasatellite recombinations is different from the occurrence of defective DNA (dfDNA) of begomovirus (Tahir et al. 2017). The dfDNA is the result of incomplete replication, thus creating significant deletions of the genome, while recombination is likely to be a result of transreplication (Nawaz-ul Rehman et al. 2009).

\section{Conclusions}

The chili sample we collected from the highland area was infected by PepYLCIV with a DNA satellite. The satellite found in this study have similar characteristic with other common betasatellites including the common stem-loop region, adenine rich region, sized around $1.3 \mathrm{kbp}$, except imperfect predictive ORF which considering the satellite is a non-coding. The non-coding satellite DNA found to be associated with PepYLCIV in this study is thought to be the result of recombination due to multiple infections in plants. Further, it is necessary to examine the role of this non-coding satellite in understanding the evolution of begomovirus and its satellites.

\section{Acknowledgments}

This research is a part of the Master Thesis by Argawi Kandito. We would like to thank Universitas Gadjah Mada for funding this research by RTA UGM 2019 grant scheme.

\section{Authors' contributions}

SH, SS, SS designed the study. AK carried out the laboratory work. AK, SH, SS analyzed the data. AK, SH, SS, SS wrote the manuscript. All authors read and approved the final version of the manuscript

\section{Competing interests}

The author declare that they have no competing interest.

\section{References}

Agnihotri AK, Mishra SP, Tripathi RC, Ansar M, Srivastava A, Tripathi IP. 2018. First natural co-occurrence of tomato leaf curl New Delhi virus DNA-A and chili leaf curl betasatellite on tomato plants (Solanum lycopersicum L.) in India. J Gen Plant Pathol. 84(6):414-417. doi:10.1007/s10327-018-0807-2.

Briddon RW, Mansoor S, Bedford ID, Pinner MS, Saunders K, Stanley J, Zafar Y, Malik KA, Markham PG. 2001. Identification of DNA components required for induction of cotton leaf curl disease. Virology. 285(2):234-243. doi:10.1006/viro.2001.0949.

Briddon RW, Patil BL, Bagewadi B, Nawaz-Ul-Rehman MS, Fauquet CM. 2010. Distinct evolutionary histories of the DNA-A and DNA-B components of bipartite begomoviruses. BMC Evol Biol. 10(1). doi:10.1186/1471-2148-10-97.

Briddon RW, Stanley J. 2006. Subviral agents associated with plant single-stranded DNA viruses 344(1):198210. doi:10.1016/j.virol.2005.09.042.

Dry IB, Krake LR, Rigden JE, Rezaian MA. 1997. A novel subviral agent associated with a geminivirus: The first report of a DNA satellite. Proc Natl Acad Sci USA. 94(13):7088-7093. doi:10.1073/pnas.94.13.7088.

Efron B, Halloran E, Holmes S. 1996. Bootstrap confidence levels for phylogenetic trees. Proc Natl Acad Sci USA. 93(23):13429-13434. doi:10.1073/pnas.93.23.13429.

Emmanuel CJ, Manohara S, Shaw MW. 2020. Molecular characterization of begomovirus-betasatellitealphasatellite complex associated with okra enation 
leaf curl disease in Northern Sri Lanka. 3 Biotech 10(12). doi:10.1007/s13205-020-02502-z.

Fiallo-Olivé E, Navas-Castillo J. 2020. Molecular and Biological Characterization of a New World Mono/Bipartite Begomovirus/Deltasatellite Complex Infecting Corchorus siliquosus. Front Microbiol. 11. doi:10.3389/fmicb.2020.01755.

Giovanni AC, Hartono S, Sulandari S, Somowiyarjo S. 2020. Molecular Identification of Begomovirus Infecting Angled Luffa. Jurnal Perlindungan Tanaman Indonesia. 24(2):147. doi:10.22146/jpti.31073.

Hidayat S, Rusli E, Nooraidawati. 1999. Penggunaan primer universal dalam polymerase chain reaction untuk mendeteksi virus gemini pada cabe [The Use of Universal Primers on PCR to Detect Geminivirus on Chili]. In: Prosiding Seminar Ilmiah dan Kongres Nasional PFI XV. Purwokerto.

Huang C, Xie Y, Zhao L, Ren H, Li Z. 2013. A naturally occurring defective DNA satellite associated with a monopartite begomovirus: Evidence for recombination between alphasatellite and betasatellite. Viruses. 5(9):2116-2128. doi:10.3390/v5092116.

Idris AM, Shahid MS, Briddon RW, Khan AJ, Zhu JK, Brown JK. 2011. An unusual alphasatellite associated with monopartite begomoviruses attenuates symptoms and reduces betasatellite accumulation. J Gen Virol. 92(3):706-717. doi:10.1099/vir.0.025288-0.

Kandito A, Hartono S, Sulandari S, Somowiyarjo S, Widyasari YA. 2020. First report of naturally occurring recombinant non-coding dna satellite associated with tomato yellow leaf curl kanchanaburi virus on eggplant in Indonesia. Biodiversitas. 21(1):129-136. doi:10.13057/biodiv/d210117.

Kenyon L, Tsai WS, Shih SL, Lee LM. 2014. Emergence and diversity of begomoviruses infecting solanaceous crops in East and Southeast Asia. Virus Res. 186:104113. doi:10.1016/j.virusres.2013.12.026.

Kintasari T, Septariani DWN, Sulandari S, Hidayat S. Tomato yellow leaf curl Kanchanaburi virus Associated with Yellow Mosaic Disease of Eggplant in Java. Jurnal Fitopatologi Indonesia. 9(4):127-131.

Kon T, Hidayat SH, Hase S, Takahashi H, Ikegami M. 2006. The natural occurrence of two distinct begomoviruses associated with DNA $\beta$ and a recombinant DNA in a tomato plant from Indonesia. Phytopathology. 96(5):517-525. doi:10.1094/PHYTO-96-0517.

Kumar R, Palicherla SR, Mandal B, Kadiri S. 2018. PCR based detection of betasatellite associated with the begomoviruses using improved universal primers. Australas Plant Pathol. 47(1):115-118. doi:10.1007/s13313-017-0537-5.

Kumar S, Stecher G, Tamura K. 2016. MEGA7: Molecular Evolutionary Genetics Analysis Version 7.0 for Bigger Datasets. Mol Biol Evol. 33(7):1870-1874. doi:10.1093/molbev/msw054.

Kusumaningrum F, Hartono S, Sulandari S, Somowiyarjo S. 2017. Infeksi Ganda Begomovirus Dan Crinivirus Pada Tanaman Tomat Di Kabupaten Magelang ,
Jawa Tengah (Double Infections of Begomovirus and Crinivirus on Tomato Plants At Magelang Regency, Central Java). Jurnal Perlindungan Tanaman Indonesia. 19(2):60. doi:10.22146/jpti.17542.

Lole KS, Bollinger RC, Paranjape RS, Gadkari D, Kulkarni SS, Novak NG, Ingersoll R, Sheppard HW, Ray SC. 1999. Full-Length Human Immunodeficiency Virus Type 1 Genomes from Subtype C-Infected Seroconverters in India, with Evidence of Intersubtype Recombination. J Virol. 73(1):152-160. doi:10.1128/jvi.73.1.152-160.1999.

Lozano G, Trenado HP, Fiallo-Olivé E, Chirinos D, Geraud-Pouey F, Briddon RW, Navas-Castillo J. 2016. Characterization of non-coding DNA satellites associated with sweepoviruses (Genus Begomovirus, Geminiviridae) - Definition of a distinct class of begomovirus-associated satellites. Front Microbiol. 7(FEB). doi:10.3389/fmicb.2016.00162.

Nawaz-ul Rehman MS, Mansoor S, Briddon RW, Fauquet CM. 2009. Maintenance of an Old World Betasatellite by a New World Helper Begomovirus and Possible Rapid Adaptation of the Betasatellite. J Virology. 83(18):9347-9355. doi:10.1128/jvi.00795-09.

Purwoko RR, Hartono S, Suputa, Lukman R, Wahyudin D. 2015. Emerging pepper yellow leaf curl virus and mungbean yellow mosaic virus of single Bemisia tabaci in Java, Indonesia. In: The 11th International Student Conference at Ibaraki University, volume 11. Japan. doi:10.13140/RG.2.1.4382.9849.

Rojas MR. 1993. Use of Degenerate Primers in the Polymerase Chain Reaction to Detect WhiteflyTransmitted Geminiviruses. Plant Dis. 77(4):340. doi:10.1094/pd-77-0340.

Saeed M, Zafar Y, Randles JW, Rezaian MA. 2007. A monopartite begomovirus-associated DNA beta satellite substitutes for the DNA B of a bipartite begomovirus to permit systemic infection. J Gen Virol. Pt 10:2881-2889. doi:10.1099/vir.0.83049-0.

Saunders K, Norman A, Gucciardo S, Stanley J. 2004. The DNA $\beta$ satellite component associated with ageratum yellow vein disease encodes an essential pathogenicity protein ( $\beta$ C1). Virology. 324(1):37-47. doi:10.1016/j.virol.2004.03.018.

Sidik E, Hartono S, Sulandari S, Lukman R, Affifudin A, Wahyudin D, Santoso H. Molecular evidence for mixed infection of four begomovirus in common bean and yard long bean showing severe yellow symptoms in East Java, Indonesia. In: Proc 1st Intl Conf Trop Agric. Yogyakarta.

Sulandari S, Suseno R, Hidayat SH, Harjosudarmo K, Sosromarsono S. 2001. Deteksi virus Gemini pada cabai di Daerah Istimewa Yogyakarta [Detection of Geminivirus on Chili in Special Region of Yogyakarta]. In: Prosiding Kongres Nasional XVI dan Seminar Ilmiah PFI. Bogor. Indonesia.

Tahir MN, Hameed A, Amin I, Mansoor S. 2017. Characterization of a begomovirus-betasatellite complex, producing defective molecules in spinach (Spina- 
cia oleracea L.), a new host for begomovirus and betasatellite complex in Pakistan. Plant Pathol J. 33(5):514-521. doi:10.5423/PPJ.NT.01.2017.0009.

Tsai WS, Shih SL, Green SK, Rauf A, Hidayat SH, Jan FJ. 2006. Molecular Characterization of Pepper yellow leaf curl Indonesia virus in Leaf Curl and Yellowing Diseased Tomato and Pepper in Indonesia. Plant Dis. 90(2):247-247. doi:10.1094/pd-90-0247b.

Wilisiani F, Somowiyarjo S, Hartono S. 2014. Molecular identification of virus causing leaf curl disease Bantul isolate on melon. JPTI 18(1):47-54. doi:10.22146/jpti.15602.

Yang X, Zhou X. 2017. Betasatellites of Begomoviruses. In: Viroids and Satellites. Elsevier Inc. p. 671-678. doi:10.1016/B978-0-12-801498-1.00062-0.

Zhang T, Luan JB, Qi JF, Huang CJ, Li M, Zhou XP, Liu SS. 2012. Begomovirus-whitefly mutualism is achieved through repression of plant defences by a virus pathogenicity factor. Mol Ecol. 21(5):12941304. doi:10.1111/j.1365-294X.2012.05457.x.

Zhou X. 2013. Advances in understanding begomovirus satellites. Annu Rev Phytopathol. 51:357-381. doi:10.1146/annurev-phyto-082712-102234. 